\title{
The identity of the Sri Lankan Amblypharyngodon (Teleostei, Cyprinidae)
}

\author{
Hiranya Sudasinghe ${ }^{1,2}$, Rohan Pethiyagoda ${ }^{3}$, Kalana Maduwage ${ }^{4}$, \\ Madhava Meegaskumbura ${ }^{5,1}$
}

I Evolutionary Ecology and Systematics Lab, Department of Molecular Biology and Biotechnology, University of Peradeniya, Peradeniya, Sri Lanka 2 Postgraduate Institute of Science, Faculty of Science, University of Peradeniya, Sri Lanka 3 Ichthyology Section, Australian Museum, 6 College Street, Sydney, NSW 2010, Australia 4 Department of Biochemistry, Faculty of Medicine, University of Peradeniya, Sri Lanka 5 Guangxi Key Laboratory of Forest Ecology \& Conservation, College of Forestry, Guangxi University, Nanning, China

Corresponding author: Madhava Meegaskumbura(madhava_m@mac.com)

Academic editor:S. Kullander | Received 13 September 2018 | Accepted 21 December 2018 | Published 28 January 2019

http://zoobank.org/7110E86F-2AEC-41A8-9A01-56117B6A1556

Citation: Sudasinghe H, Pethiyagoda R, Maduwage K, Meegaskumbura M (2019) The identity of the Sri Lankan Amblypharyngodon (Teleostei, Cyprinidae). ZooKeys 820: 25-49. https://doi.org/10.3897/zookeys.820.29632

\begin{abstract}
Morphological and molecular analyses of specimens representative of the geographic range of the cyprinid genus Amblypharyngodon in Sri Lanka suggest the presence of only a single species in the island, for which the name Amblypharyngodon grandisquamis Jordan \& Starks, 1917, is available. Amblypharyngodon grandisquamis is a species endemic to Sri Lanka, distributed across the lowlands of both of the island's main climatic zones. It is distinguished from all other species of Amblypharyngodon, including the three species recorded from peninsular India (A. mola, A. microlepis, and A. melettinus), by a suite of characters that includes a body depth of 26.9-31.2\% of the standard length (SL), 42-56 scales in the lateral series (of which usually 8-16 are pored), 20-24 circumpeduncular scales, 14-17 scale rows between the origins of the dorsal and pelvic fins, a dorsal-fin height of 21.1-27.6\% SL, 18-19 caudal vertebrae and an eye diameter of $22.7-30.5 \%$ of the head length. Amblypharyngodon grandisquamis differs from A. melettinus and $A$. mola by uncorrected pairwise genetic distances of more than $9 \%$ and $6 \%$, respectively, for the mitochondrial cytochrome oxidase subunit 1 (COI) gene.
\end{abstract}

\section{Keywords}

Amblypharyngodon grandisquamis, Amblypharyngodon melettinus, biodiversity hotspot, DNA barcoding, integrative taxonomy, island endemism

Copyright Hiranya Sudasinghe et al. This is an open access article distributed under the terms of the Creative Commons Attribution License (CC BY 4.0), which permits unrestricted use, distribution, and reproduction in any medium, provided the original author and source are credited. 


\section{Introduction}

The cyprinid genus Amblypharyngodon Bleeker, which has a range extending from the Indian subcontinent to Southeast Asia, is considered to contain just five valid species: A. atkinsonii (Blyth), A. chulabhornae Vidthayanon \& Kottelat, A. melettinus (Valenciennes), A. microlepis (Bleeker), and A. mola (Hamilton) (Vidthayanon and Kottelat 1990). The genus is characterised by having pharyngeal teeth that are compressed, with the crown blunt and enlarged; the lateral line incomplete, with 42-79 small scales in the lateral series; seven branched dorsal-fin rays; a small maximum size (standard length, SL), ranging from approximately 40 to $150 \mathrm{~mm}$; and the absence of an upper lip, barbels, and fleshy labial folds (Vidthayanon and Kottelat 1990).

The genus was first reported from Sri Lanka by Günther (1868: 202), who identified specimens from the island as Leuciscus melettina Valenciennes, in Cuvier and Valenciennes 1844 (hereafter Valenciennes 1844), type locality Bombay [Mumbai], India. Jordan and Starks (1917) described a second species from Sri Lanka, A. grandisquamis (type locality "river at Colombo"), which they distinguished from $A$. melettinus as follows: "This species is closest to Amblypharyngodon melettinus, but is deeper and has much larger scales". Since then, the identity of the species of Amblypharyngodon inhabiting Sri Lanka has been confused, with some authors considering only $A$. melettinus to be present in the island (e.g., Deraniyagala 1952: 45, Senanayake 1980: 167, Pethiyagoda 1991: 25), while others consider both A. melettinus and A. grandisquamis to be present (Pethiyagoda 2006, MOE 2012, De Silva et al. 2015). No specimenbased study has been conducted to resolve this confusion until now.

Here we review Sri Lankan Amblypharyngodon using an integrative taxonomic approach (Dayrat 2005) that combines morphological and molecular data, and show that only a single species is present in the island, for which the name $A$. grandisquamis Jordan \& Starks, 1917 is available.

\section{Materials and methods}

\section{Metrics and meristics}

Measurements and counts follow Sudasinghe et al. (2018a) except that the lateral-line scale count is given as the number of pored lateral-line scales + the scales between the last pored scale and the base of the hypural plate. In addition, the pelvic-anal distance was measured between the origins of the pelvic and anal fins, respectively. All counts and measurements were taken on the left side of specimens whenever possible. Body measurements and head length are given as proportions of standard length; and subunits of the head as proportions of head length. Values in parentheses following a count indicate the frequency of that count. Vertebral counts and osteological descriptions are based on cleared and stained specimens following the single-staining method of Taylor and Van Dyke (1985). Osteological descriptions follow Vidthayanon and Kottelat (1990) and Conway (2011). 
Comparative data for A. chulabhornae and (in part) A. atkinsonii and A. microlepis are from Vidthayanon and Kottelat (1990).

\section{Material}

Specimens referred to in the text are deposited in the collections of Muséum national d'Histoire naturelle, Paris, France (MNHN); Stanford University, Palo Alto, California, USA. Some specimens are on long term loan to the California Academy of Sciences, San Francisco (CAS-SU); Field Museum of Natural History, Chicago, USA (FMNH); Australian Museum, Sydney (AMS); the Wildlife Heritage Trust of Sri Lanka (WHT), now at the National Museum of Sri Lanka; Bombay Natural History Society, Mumbai, India (BNHS); and the Department of Molecular Biology and Biotechnology, University of Peradeniya, Sri Lanka (DZ).

\section{Comparative material}

Amblypharyngodon melettinus (all from India): MNHN 3812, Leuciscus melettina, 5, syntypes, 60.7-65.7 mm SL, India, Bombay; WHT 7419, 6, 57.9-75.2 mm SL, Kerala, Kumarakom, Kottayam; WHT 7420, 6, 59.9-74.5 mm SL, Kerala, Kumarakom, Kottayam; WHT 30329-31, 3, 45.8-51.4 mm SL, Kerala, Nedumudi, Alappuzha; WHT 30787, 4, 72.5-77.3 mm SL, Kerala, Changanasserry to Alappuzha. Cleared and stained: WHT 11072, $57.6 \mathrm{~mm} \mathrm{SL}$, Kerala and WHT 11079, $49.6 \mathrm{~mm}$ SL, Kerala.

A. cf. mola: BNHS 560-61, 2, 44.5-56.8 mm SL, India, Maharashtra, Vaitarna River, Tilase.

A. mola: WHT30316, 5, 43.2-47.5 mm SL, India, 24 Parganas, West Bengal.

A. microlepis: AMS B7593, 62.5 mm SL, India, Orissa.

A. atkinsonii: AMS B7865, Mola atkinsonii, syntype, $79.4 \mathrm{~mm}$ SL, Myanmar, Prome [Pyay].

\section{Morphometric analysis}

A Principal Component Analysis (PCA) in a covariance matrix was carried out to identify variables that best discriminate among the species. In view of one of us (HS) having measured the recent material and another (RP) having measured the historical material (the types of Leuciscus melettinus and Amblypharyngodon grandisquamis), and in order to account for the deforming of specimens through long-term storage in preservative, the respective datasets were analysed separately. Prior to the PCA, all measurements were size-corrected by using the equation

$$
M_{s}=M_{o}\left(\frac{L_{s}}{L_{o}}\right)^{b}
$$


where $M_{\mathrm{s}}$ is the size corrected measurement, $M_{\mathrm{o}}$ is the measured character, $L_{\mathrm{s}}$ is the overall (arithmetic) mean standard length for all individuals from all populations of all putative species, and $L_{\mathrm{o}}$ is the standard length of the specimen, while $b$ is calculated for each character from the observed data by using the allometric-growth equation $M=a L^{b}$ in which $b$ is the gradient of regression of $\log M_{\mathrm{o}}$ on $\log L_{\mathrm{o}}$ (Elliott et al. 1995). The software PAST (Hammer et al. 2001) was used to carry out the PCA.

\section{Molecular analysis}

The protocols for DNA extraction, PCR amplification and PCR product purification for the mitochondrial cytochrome oxidase subunit 1 (COI) and 16s rRNA subunit (16s) follow Sudasinghe et al. (2018a), while those for the mitochondrial cytochrome b (cytb) gene follow Sudasinghe et al. (2018b).

Sequences were checked and assembled in ChromasPro v1.34 (Technelysium Pty Ltd) and contig sequences of the two strands were constructed using MEGA v.7.0 (Kumar et al. 2016). The 16s, COI, and cytb contig datasets were prepared and aligned separately using ClustalW in MEGA v. 7.0 (Kumar et al. 2016) and verified manually. Protein-coding genes (COI and cytb) were translated and checked for internal stop codons or frameshift mutations. Details of the specimens used in the molecular analysis, together with additional GenBank sequences used, are given in Table 1. The uncorrected pairwise genetic distances for species of Amblypharyngodon for the three genes were calculated using MEGA. For each independent dataset, $16 \mathrm{~s}$ (497 bp) and COI (654 bp), and a combined dataset of 16s+COI (1151 bp), a Bayesian phylogenetic inference was carried out using MrBayes v3.2 (Ronquist et al. 2012). A phylogenetic analysis for cytb was not carried out due to the paucity of comparative sequences in GenBank. For the Bayesian phylogenetic inference, the best-fitting nucleotide substitution model for each gene partition (16s and COI) was selected using jModelTest v.2.1.6 (Guindon and Gascuel 2003, Darriba et al. 2012) under the Bayesian information criterion (BIC). Four Metropolis coupled Markov chain Monte Carlo (MCMCMC) chains were run for 1 million generations for each analysis with a sample frequency of 100 . The first $0.1 \%$ of generations was discarded as burn-in, after determining with Tracer v1.6 (Rambaut et al. 2014). The posterior probabilities (PP) of the clades (Huelsenbeck et al. 2001) were computed by using the frequency of the remaining clades in trees that were sampled every one hundred generations. Figtree v.1.4.3 (http://tree.bio.ed.ac.uk/software/figtree) was used to visualise the trees obtained from the Bayesian analyses.

Haplotype network reconstruction for the 16s, COI, and cytb genes of the various populations of Amblypharyngodon was inferred by TCS network (Clement et al. 2002) in PopArt (Leigh and Bryant 2015). DNAsp v.6 (Rozas et al. 2017) was used to compute the nucleotide diversity $(\pi)$, haplotype diversity and neutrality tests: Tajima's D (Tajima 1989) and Fu and Li’s F (Fu and Li 1993). 
Table I. Species included in the phylogenetic analysis, with their localities, voucher references, and GenBank accession numbers.

\begin{tabular}{|c|c|c|c|c|c|c|c|}
\hline Species & Voucher & Location & $\begin{array}{c}\text { GPS } \\
\text { coordinates }\end{array}$ & Source & $16 s$ & COI & cytb \\
\hline \multirow[t]{14}{*}{$\begin{array}{l}\text { Amblypharyngodon } \\
\text { grandisquamis }\end{array}$} & DZ 1504 & $\begin{array}{c}\text { Sri Lanka: Mahaweli River basin, } \\
\text { Ulhitiya }\end{array}$ & $\begin{array}{l}07.38 \mathrm{~N} \\
81.09 \mathrm{E}\end{array}$ & This study & MH884614 & MH884634 & MH884638 \\
\hline & DZ 3175 & $\begin{array}{c}\text { Sri Lanka: Mahaweli River basin, } \\
\text { Polonnaruwa }\end{array}$ & $\begin{array}{l}07.87 \mathrm{~N} \\
80.96 \mathrm{E}\end{array}$ & This study & MH884615 & MH884633 & MH884639 \\
\hline & DZ 3176 & $\begin{array}{c}\text { Sri Lanka: Mahaweli River basin, } \\
\text { Polonnaruwa }\end{array}$ & $\begin{array}{l}07.87 \mathrm{~N} \\
80.96 \mathrm{E}\end{array}$ & This study & MH884616 & MH884632 & MH884643 \\
\hline & DZ 3434 & $\begin{array}{c}\text { Sri Lanka: Mahaweli River basin, } \\
\text { Naula, Matale }\end{array}$ & $\begin{array}{l}07.52 \mathrm{~N} \\
80.64 \mathrm{E}\end{array}$ & This study & MH884617 & MH884628 & NA \\
\hline & WHT 81 & $\begin{array}{c}\text { Sri Lanka: Mahaweli River basin, } \\
\text { Elahera }\end{array}$ & NA & This study & MH884618 & NA & MH884645 \\
\hline & WHT 92 & $\begin{array}{c}\text { Sri Lanka: Mahaweli River basin, } \\
\text { Minneriya }\end{array}$ & NA & This study & MH884619 & NA & MH884646 \\
\hline & DZ 3376 & $\begin{array}{c}\text { Sri Lanka: Walawe River basin, } \\
\text { Samanala reservoir }\end{array}$ & $\begin{array}{l}06.69 \mathrm{~N} \\
80.78 \mathrm{E}\end{array}$ & This study & MH884620 & MH884630 & MH884640 \\
\hline & DZ 3377 & $\begin{array}{l}\text { Sri Lanka: Walawe River basin, } \\
\text { Samanala reservoir }\end{array}$ & $\begin{array}{l}06.69 \mathrm{~N} \\
80.78 \mathrm{E}\end{array}$ & This study & MH884621 & MH884629 & MH884641 \\
\hline & DZ 3292 & $\begin{array}{l}\text { Sri Lanka: Kalu River basin, } \\
\text { Remuna, Horana }\end{array}$ & $\begin{array}{l}06.69 \mathrm{~N} \\
80.07 \mathrm{E}\end{array}$ & This study & MH884622 & MH884631 & MH884642 \\
\hline & DZ 3854 & $\begin{array}{c}\text { Sri Lanka: Attanagalu Oya basin, } \\
\text { Yakkala }\end{array}$ & $\begin{array}{l}07.07 \mathrm{~N} \\
80.07 \mathrm{E}\end{array}$ & This study & MH884623 & MH884637 & NA \\
\hline & DZ 3855 & $\begin{array}{c}\text { Sri Lanka: Attanagalu Oya basin, } \\
\text { Yakkala }\end{array}$ & $\begin{array}{l}07.07 \mathrm{~N} \\
80.07 \mathrm{E}\end{array}$ & This study & MH884624 & MH884636 & NA \\
\hline & DZ 3856 & $\begin{array}{c}\text { Sri Lanka: Attanagalu Oya basin, } \\
\text { Yakkala }\end{array}$ & $\begin{array}{l}07.07 \mathrm{~N} \\
80.07 \mathrm{E}\end{array}$ & This study & MH884625 & MH884635 & NA \\
\hline & WHT 38 & Sri Lanka: Menik River basin & NA & This study & MH884626 & NA & MH884644 \\
\hline & WHT 101 & $\begin{array}{c}\text { Sri Lanka: Kala Oya basin, } \\
\text { Nocchiyagama }\end{array}$ & NA & This study & MH884627 & NA & MH884647 \\
\hline \multirow{5}{*}{$\begin{array}{l}\text { Amblypharyngodon } \\
\text { melettinus }\end{array}$} & Am2 & India: Kerala & NA & GenBank & FJ751268 & NA & NA \\
\hline & Am1 & India: Kerala & NA & GenBank & FJ751267 & FJ751272 & NA \\
\hline & $\mathrm{ACI}$ & India: Kerala & NA & GenBank & FJ751266 & FJ751271 & NA \\
\hline & $\mathrm{A} 2$ & India: Kerala & NA & GenBank & FJ751265 & FJ751270 & NA \\
\hline & $\mathrm{A} 1$ & India: Kerala & NA & GenBank & FJ751264 & FJ751269 & NA \\
\hline \multirow[t]{15}{*}{$\begin{array}{l}\text { Amblypharyngodon } \\
\text { mola }\end{array}$} & $\begin{array}{l}\text { NBFGRMU } \\
\text { AM8004L }\end{array}$ & India & $\begin{array}{l}23.32 \mathrm{~N} \\
91.28 \mathrm{E}\end{array}$ & GenBank & KT878048 & NA & NA \\
\hline & $\begin{array}{l}\text { NBFGRMU } \\
\text { AM8004K }\end{array}$ & India & $\begin{array}{l}23.32 \mathrm{~N} \\
91.28 \mathrm{E}\end{array}$ & GenBank & KT878047 & NA & NA \\
\hline & $\begin{array}{l}\text { NBFGRMU } \\
\text { AM8004H }\end{array}$ & India & $\begin{array}{l}23.32 \mathrm{~N} \\
91.28 \mathrm{E}\end{array}$ & GenBank & KT878046 & NA & NA \\
\hline & $\begin{array}{l}\text { NBFGRMU } \\
8004 \mathrm{~S}\end{array}$ & India & $\begin{array}{l}24.39 \mathrm{~N} \\
93.58 \mathrm{E}\end{array}$ & GenBank & KT878045 & NA & NA \\
\hline & $\begin{array}{l}\text { NBFGRMU } \\
8004 \mathrm{M}\end{array}$ & India & $\begin{array}{l}24.30 \mathrm{~N} \\
93.46 \mathrm{E}\end{array}$ & GenBank & KT878044 & KT896674 & NA \\
\hline & $\begin{array}{c}\text { PUMNH } \\
28 / 2013\end{array}$ & India & NA & GenBank & NA & KX266827 & NA \\
\hline & $8004 Q$ & India & $\begin{array}{l}24.34 \mathrm{~N} \\
93.46 \mathrm{E}\end{array}$ & GenBank & NA & KX245049 & NA \\
\hline & $8004 \mathrm{P}$ & India & $\begin{array}{l}24.34 \mathrm{~N} \\
93.46 \mathrm{E}\end{array}$ & GenBank & NA & KX245048 & NA \\
\hline & 80040 & India & $\begin{array}{l}24.34 \mathrm{~N} \\
93.46 \mathrm{E}\end{array}$ & GenBank & NA & KX245047 & NA \\
\hline & $8004 \mathrm{~N}$ & India & $\begin{array}{l}24.34 \mathrm{~N} \\
93.46 \mathrm{E}\end{array}$ & GenBank & NA & KX245046 & NA \\
\hline & DUZM031 & $\begin{array}{l}\text { Bangladesh: Tanguar Haor, } \\
\text { Sunamganj }\end{array}$ & $\begin{array}{l}25.08 \mathrm{~N} \\
91.33 \mathrm{E}\end{array}$ & GenBank & NA & KT364774 & NA \\
\hline & AM-1005 & India & $\begin{array}{l}25.76 \mathrm{~N} \\
89.95 \mathrm{E}\end{array}$ & GenBank & NA & KJ936819 & NA \\
\hline & AM-1004 & India & $\begin{array}{l}25.76 \mathrm{~N} \\
89.95 \mathrm{E}\end{array}$ & GenBank & NA & KJ936818 & NA \\
\hline & AM-1003 & India & $\begin{array}{l}25.76 \mathrm{~N} \\
89.95 \mathrm{E}\end{array}$ & GenBank & NA & KJ936817 & NA \\
\hline & AM-1002 & India & $\begin{array}{l}25.76 \mathrm{~N} \\
89.95 \mathrm{E}\end{array}$ & GenBank & NA & KJ936816 & NA \\
\hline
\end{tabular}




\begin{tabular}{|c|c|c|c|c|c|c|c|}
\hline Species & Voucher & Location & $\begin{array}{c}\text { GPS } \\
\text { coordinates }\end{array}$ & Source & $16 s$ & COI & cytb \\
\hline \multirow[t]{19}{*}{$\begin{array}{l}\text { Amblypharyngodon } \\
\text { mola }\end{array}$} & AM-1001 & India & $\begin{array}{l}25.76 \mathrm{~N} \\
89.95 \mathrm{E}\end{array}$ & GenBank & NA & KJ936815 & NA \\
\hline & AM-2005 & India & $\begin{array}{r}24.29 \mathrm{~N} \\
92.63 \mathrm{E}\end{array}$ & GenBank & NA & KJ936763 & NA \\
\hline & AM-2004 & India & $\begin{array}{l}24.29 \mathrm{~N} \\
92.63 \mathrm{E}\end{array}$ & GenBank & NA & KJ936762 & NA \\
\hline & AM-2003 & India & $\begin{array}{l}24.29 \mathrm{~N} \\
92.63 \mathrm{E}\end{array}$ & GenBank & NA & KJ936761 & NA \\
\hline & AM-2002 & India & $\begin{array}{r}24.29 \mathrm{~N} \\
92.63 \mathrm{E}\end{array}$ & GenBank & NA & KJ936760 & NA \\
\hline & AM-2001 & India & $\begin{array}{r}24.29 \mathrm{~N} \\
92.63 \mathrm{E}\end{array}$ & GenBank & NA & KJ936759 & NA \\
\hline & NF770 & $\begin{array}{l}\text { India: Gujarat, Bharuch, Estuary, } \\
\text { Bharuch }\end{array}$ & $\begin{array}{l}21.68 \mathrm{~N} \\
73.45 \mathrm{E}\end{array}$ & GenBank & NA & JX983212 & NA \\
\hline & NF771 & $\begin{array}{c}\text { India: Gujarat, Bharuch, Estuary, } \\
\text { Bharuch }\end{array}$ & $\begin{array}{l}21.68 \mathrm{~N} \\
73.45 \mathrm{E}\end{array}$ & GenBank & NA & JX983211 & NA \\
\hline & PRUM01 & $\begin{array}{l}\text { India: Maharashtra, Vidarbha, } \\
\text { Umarkhed Painganga }\end{array}$ & $\begin{array}{l}19.59 \mathrm{~N} \\
77.68 \mathrm{E}\end{array}$ & GenBank & NA & JX260822 & NA \\
\hline & GF675 & $\begin{array}{c}\text { India: Maharashtra, Marathwada, } \\
\text { Kaigaon }\end{array}$ & $\begin{array}{l}19.62 \mathrm{~N} \\
75.01 \mathrm{E}\end{array}$ & GenBank & NA & JX260821 & NA \\
\hline & BESH02 & $\begin{array}{c}\text { India: Maharashtra, Shahagad } \\
\text { River Pool Cad }\end{array}$ & $\begin{array}{l}19.36 \mathrm{~N} \\
75.71 \mathrm{E}\end{array}$ & GenBank & NA & JX260820 & NA \\
\hline & PSSH02 & $\begin{array}{c}\text { India: Maharashtra, Shahagad } \\
\text { River Pool Cad }\end{array}$ & $\begin{array}{l}19.36 \mathrm{~N} \\
75.71 \mathrm{E}\end{array}$ & GenBank & NA & JX260819 & NA \\
\hline & GF679 & $\begin{array}{c}\text { India: Maharashtra, Marathwada, } \\
\text { Kaigaon }\end{array}$ & $\begin{array}{l}19.62 \mathrm{~N} \\
75.01 \mathrm{E}\end{array}$ & GenBank & NA & JX260818 & NA \\
\hline & GDK025-11 & $\begin{array}{l}\text { India: Maharashtra, Shahagad } \\
\text { River Pool Cad }\end{array}$ & $\begin{array}{l}19.36 \mathrm{~N} \\
75.71 \mathrm{E}\end{array}$ & GenBank & NA & JX260817 & NA \\
\hline & DOF16 & India & $\begin{array}{l}24.46 \mathrm{~N} \\
93.01 \mathrm{E}\end{array}$ & GenBank & NA & JN815278 & NA \\
\hline & DOF15 & India & $\begin{array}{l}24.46 \mathrm{~N} \\
93.01 \mathrm{E}\end{array}$ & GenBank & NA & JN815277 & NA \\
\hline & CTOL01907 & NA & NA & GenBank & NA & HM224137 & HM224256 \\
\hline & AM2 & India & NA & GenBank & NA & NA & KX389702 \\
\hline & AM1 & India & NA & GenBank & NA & NA & KX389701 \\
\hline \multirow{3}{*}{$\begin{array}{l}\text { Amblypharyngodon } \\
\text { chulabhornae }\end{array}$} & NA & NA & NA & GenBank & AP012114 & AP012114 & AP012114 \\
\hline & NA & NA & NA & GenBank & U21380 & NA & NA \\
\hline & CTOL01544 & NA & NA & GenBank & NA & NA & HM224255 \\
\hline Barilius vagra & CTOL03301 & NA & NA & GenBank & NA & HM224140 & HM224259 \\
\hline \multirow[t]{3}{*}{ Barilius gatensis } & 4BG & India & NA & GenBank & NA & KF853168 & NA \\
\hline & 6BG & India & NA & GenBank & KF853144 & NA & NA \\
\hline & $5 B G$ & India & NA & GenBank & KF853143 & NA & NA \\
\hline Salmostoma phulo & CTOL03316 & NA & NA & GenBank & NA & HM224248 & HM224379 \\
\hline \multirow[t]{3}{*}{ Salmostoma bacaila } & WL-F38 & India & NA & GenBank & NA & EU417789 & NA \\
\hline & $\begin{array}{l}\text { NBFGRMU } \\
\quad 8020 \mathrm{G}\end{array}$ & India & $\begin{array}{l}24.42 \mathrm{~N} \\
93.04 \mathrm{E}\end{array}$ & GenBank & KT878279 & NA & NA \\
\hline & $\begin{array}{l}\text { NBFGRMU } \\
8020 \mathrm{~F}\end{array}$ & India & $\begin{array}{l}24.42 \mathrm{~N} \\
93.04 \mathrm{E}\end{array}$ & GenBank & KT878278 & NA & NA \\
\hline
\end{tabular}

\section{Results}

\section{Molecular analysis}

The $\mathrm{HKY}+\mathrm{G}$ model was chosen as the best-fit nucleotide-substitution model under $\mathrm{BIC}$ in the jModelTest for the COI dataset. In the Bayesian phylogenetic inference for the COI dataset, $A$. mola was recovered as the sister species of $A$. grandisquamis, though weakly supported ( $\mathrm{PP}=66$, Figure 1A). The GenBank sequence JX260817 Amblypharyngodon sp nests within the rest of the sequences of $A$. mola. 
The SYM+G model was chosen as the best-fit nucleotide-substitution model under BIC in the jModelTest for the Bayesian phylogenetic inference of the 16s dataset. Here, Amblypharyngodon melettinus was recovered as the sister species of $A$. grandisquamis ( $\mathrm{PP}=85$, Figure $1 \mathrm{C}$ ). The GenBank sequences FJ751266 as A. chakaiensis, FJ751264-65 as $A$. melettinus 'muriyadensis' nest with the other sequences of $A$. melettinus (FJ751267-68) available in GenBank.

In the combined 16s+COI (1151 bp) Bayesian phylogenetic inference, A. mola was recovered as the sister species of $A$. grandisquamis $(\mathrm{PP}=89)$ while $A$. melettinus was recovered as the sister species of $[$ A. grandisquamis + A. mola $](\mathrm{PP}=100)$.

The uncorrected pairwise genetic distances obtained for the 16s, COI, and cytb genes for the species of Amblypharyngodon is given in Table 2. Amblypharyngodon grandisquamis differs genetically from $A$. melettinus, $A$. mola, and $A$. chulabhornae by uncorrected pairwise distances of more than $4 \%$ for the 16 s gene fragment, while the intraspecific divergence within $A$. grandisquamis for the same gene is only $0.0-0.4 \%$. For COI, $A$. grandisquamis differs from $A$. melettinus, $A$. mola, and $A$. chulabhornae by uncorrected pairwise genetic distances of more than $9 \%, 6 \%$, and $10 \%$, respectively, while the intraspecific genetic divergence within $A$. grandisquamis for the same gene is only $0.0-1.9 \%$. With respect to cytb, $A$. grandisquamis differs from $A$. mola and $A$. chulabhornae by uncorrected pairwise genetic distances of more than $7 \%$ and $14 \%$, respectively, while the intraspecific genetic divergence within $A$. grandisquamis for the same gene is $0.0-4.2 \%$ (there are no cytb sequences available for $A$. melettinus). DZ 3292 from Remuna, Kalu basin (wet zone) differs from the other Sri Lankan samples by 3.2-4.2\%, while WHT 101 from Nochiyagama, Kala Oya basin (dry zone) differs from them by $1.8-2.5 \%$.

In the COI haplotype network, the dry zone and wet zone samples of $A$. grandisquamis form a shared a haplotype (H1) (Figure 1B). A single unique haplotype (H3) occurs in the wet zone, while three unique haplotypes are recorded from the dry zone $(\mathrm{H} 2, \mathrm{H} 4, \mathrm{H} 5)$ (Figure 1B). Populations of $A$. grandisquamis (ten sequences) included 12 segregating sites and five parsimony-informative sites. The nucleotide diversity and haplotype diversity for A. grandisquamis were 0.0073 and 0.800 , respectively. Tajima's $\mathrm{D}$ test and $\mathrm{Fu}$ and Li's $\mathrm{F}^{*}$ test statistic were both negative $(-0.16285,-0.65621)$ but not significant $(\mathrm{p}>0.05, \mathrm{p}>0.02)$.

Only three haplotypes occur in the 16s haplotype of $A$. grandisquamis (Figure 1D). These include a haplotype (H1) shared between populations of the dry and wet zones, together with a unique dry zone $(\mathrm{H} 3)$ and unique wet zone $(\mathrm{H} 2)$ haplotype. Populations of A. grandisquamis (14 sequences) included two segregating sites and a single parsimony-informative site. The nucleotide diversity and haplotype diversity for $A$. grandisquamis were 0.00139 and 0.582 , respectively. Tajima's D test was positive (0.17874) and Fu and Li's $\mathrm{F}^{*}$ test statistic was negative $(-0.32441)$, but neither was significant $(\mathrm{p}>0.05, \mathrm{p}>0.02)$.

In the cytb haplotype network for $A$. grandisquamis, the only representative of the wet zone population (DZ 3292) in our molecular analysis formed a unique haplotype, while the dry zone samples formed four unique haplotypes. Populations of $A$. grandisquamis (ten sequences) included 22 segregating sites and three parsimony-informative sites. The nucleotide diversity and haplotype diversity for A. grandisquamis were 0.0101 and 0.667 , respectively. Although Tajima's D test was positive (1.7016) and $\mathrm{Fu}$ and Li's $\mathrm{F}^{*}$ test statistic was negative (-2.0688), neither was significant ( $p>0.05, \mathrm{p}>0.02$, respectively). 
Table 2. Intraspecific and interspecific percentage uncorrected pairwise genetic distances, for the 16s, COI, and cytb genes, between species of Amblypharyngodon.

\begin{tabular}{|c|c|c|c|c|c|c|c|c|c|c|c|c|}
\hline \multirow[b]{2}{*}{$\%$} & \multicolumn{3}{|c|}{ A. grandisquamis } & \multicolumn{3}{|c|}{ A. melettinus } & \multicolumn{3}{|c|}{ A. mola } & \multicolumn{3}{|c|}{ A. chulabhornae } \\
\hline & $16 \mathrm{~s}$ & COI & cytb & $16 s$ & $\mathrm{COI}$ & cytb & $16 \mathrm{~s}$ & COI & cytb & $16 \mathrm{~s}$ & $\mathrm{COI}$ & cytb \\
\hline A. grandisquamis & $0.0-0.4$ & $0.0-1.9$ & $0.0-4.2$ & & & & & & & & & \\
\hline A. melettinus & $4.4-5.2$ & $9.9-11.0$ & NA & $0.0-0.4$ & $0.8-1.1$ & NA & & & & & & \\
\hline A. mola & $4.0-4.6$ & $6.6-8.3$ & $7.0-9.2$ & $5.6-6.3$ & $9.6-10.7$ & NA & $0.0-0.6$ & $0.0-0.8$ & $0.0-0.4$ & & & \\
\hline A. chulabhornae & $6.3-6.9$ & $10.2-10.5$ & $14.8-15.1$ & $7.3-7.9$ & $10.7-11.6$ & NA & $5.9-6.7$ & $10.7-11.0$ & $14.4-14.8$ & 0.8 & NA & 0.0 \\
\hline
\end{tabular}

A

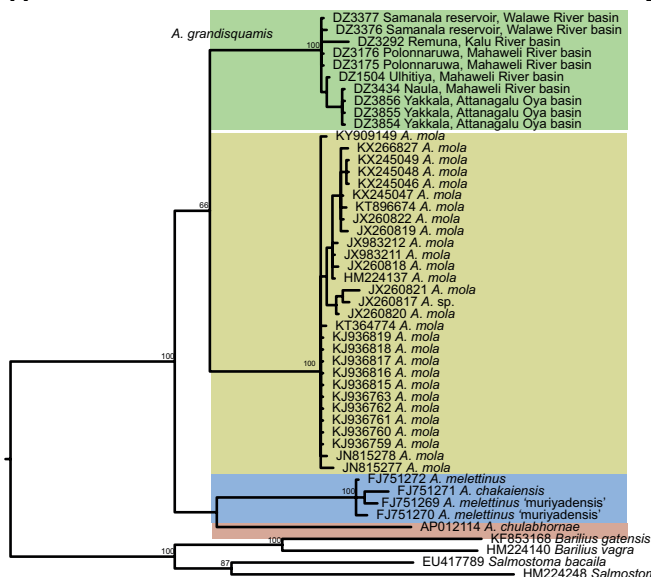

B

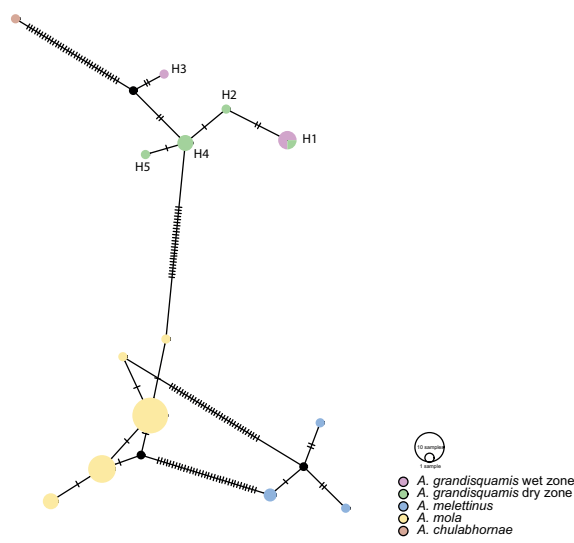

C

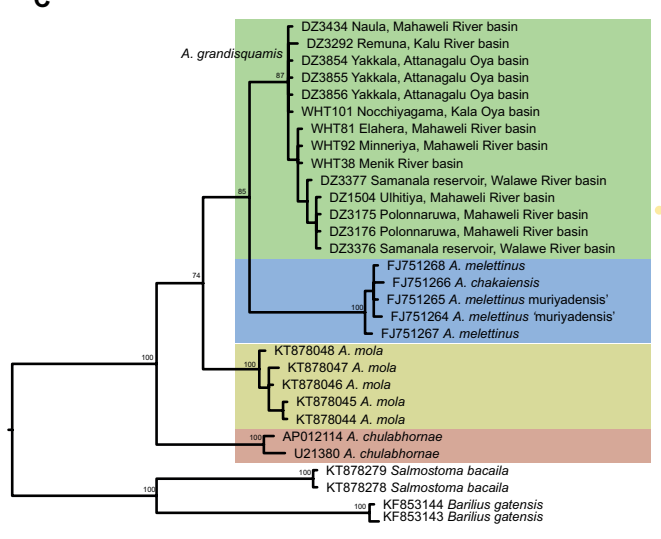

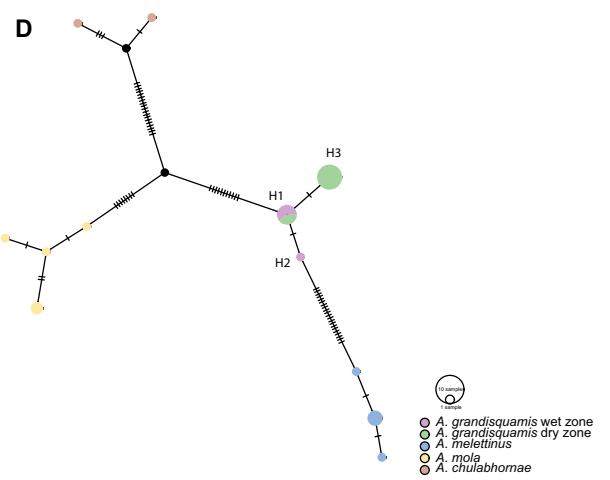

Figure I. A, $\mathbf{C}$ Phylogram based on Bayesian phylogenetic inference of $\mathbf{A}$ the $\mathrm{COI}$ and $\mathbf{C} 16$ s dataset for species of Amblypharyngodon. Numbers above nodes represent Bayesian Posterior Probabilities. The scale bar represents the number of changes per site B, D TCS haplotype network for species of Amblypharyngodon based on the analysis of $\mathbf{B}$ a 654-bp fragment of the COI gene and $\mathbf{D}$ a 497-bp fragment of the 16s gene. The sizes of the circles are proportional to the number of individuals sharing a given haplotype. The number of mutational steps is indicated by hatch marks. The black circles represent hypothetical nodes. 


\section{Statistical analysis}

The morphometric PCA of the syntypes of $A$. melettinus (MNHN 3812) and the paratypes of $A$. grandisquamis (SU 22868) clearly separate the two species into two distinct clusters, with body depth and caudal-peduncle length explaining most of the variation (Figure 2A, Table 3). Similarly, the PCA of the recent material separate A. grandisquamis, $A$. melettinus, and $A$. mola in morphological space (Figure 2B, Table 4), with only a slight overlap between $A$. grandisquamis and $A$. mola. The identity of the two specimens identified as $A$. cf. mola (BNHS 560-61) is doubtful (see Discussion). Most of the variation on PC1 is explained by pre-anal length and body depth, while the variation on PC3 is explained mostly by the dorsal-fin height.

A

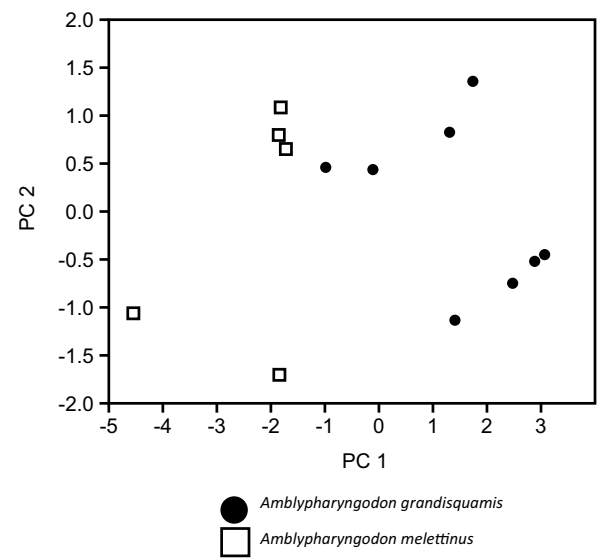

B

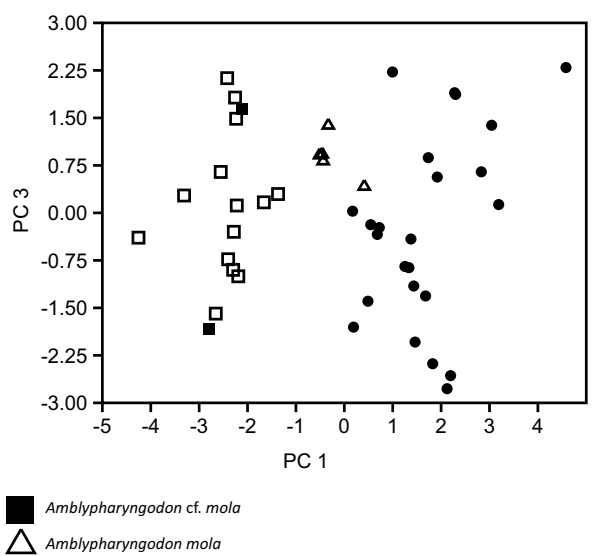

Figure 2. Plot of scores from the principal component analysis of size-corrected measurements of $\mathbf{A}$ paratypes of Amblypharyngodon grandisquamis (SU 22868) and syntypes of A. melettinus (MNHN 3812), and B recent material examined of $A$. grandisquamis, A. melettinus, $A$. mola, and $A$. cf. mola.

Table 3. Component loadings in the principal component analysis of the size-adjusted morphometric measurements of the paratypes of Amblypharyngodon grandisquamis (SU 22868) and syntypes of A. melettinus (MNHN 3812).

\begin{tabular}{lccc}
\hline & Component 1 & Component 2 & Component 3 \\
\hline Eigenvalue & 5.4435 & 0.9590 & 0.6933 \\
Variance explained & 73.725 & 12.989 & 9.3901 \\
Body depth & 0.8028 & 0.5239 & -0.1882 \\
Caudal peduncle length & 0.5863 & -0.7560 & 0.1355 \\
Caudal peduncle depth & -0.0145 & -0.0398 & -0.4534 \\
Head length & 0.0500 & 0.1730 & 0.8129 \\
Snout length & -0.0563 & 0.1567 & -0.1712 \\
Eye diameter & -0.0286 & -0.0125 & 0.0303 \\
Inter-orbital width & 0.0698 & 0.3125 & 0.2225 \\
\hline
\end{tabular}


Table 4. Component loadings in the principal component analysis of the size-adjusted morphometric measurements of the recent material of Amblypharyngodon examined in the study.

\begin{tabular}{lccc}
\hline & Component 1 & Component 2 & Component 3 \\
\hline Eigenvalue & 4.4466 & 3.2916 & 1.8519 \\
Variance explained & 30.144 & 22.314 & 12.554 \\
Predorsal length & 0.0175 & 0.3200 & -0.0137 \\
Postdorsal length & 0.2933 & -0.2495 & -0.1115 \\
Preanal length & -0.4055 & 0.2789 & 0.2023 \\
Prepelvic length & -0.2027 & 0.2117 & 0.1323 \\
Caudal peduncle length & 0.3304 & 0.0390 & -0.3040 \\
Caudal peduncle depth & 0.1731 & -0.0041 & 0.0432 \\
Body depth & 0.5663 & -0.0706 & 0.1794 \\
Dorsal-fin height & 0.0970 & -0.2158 & 0.5209 \\
Dorsal-fin base length & 0.0238 & -0.1490 & 0.1537 \\
Anal-fin height & 0.0730 & -0.0733 & 0.3317 \\
Anal-fin base length & 0.0095 & -0.1455 & 0.1407 \\
Pelvic-fin height & 0.0025 & 0.0514 & 0.3114 \\
Pelvic-fin base length & 0.0096 & 0.0160 & 0.0913 \\
Pectoral-fin length & 0.0484 & -0.2036 & 0.3004 \\
Pelvic-anal distance & -0.1957 & 0.0167 & 0.1557 \\
Head length & 0.2971 & 0.6690 & 0.0630 \\
Head depth & 0.2368 & 0.3131 & 0.3509 \\
Snout length & 0.0013 & 0.0617 & 0.0177 \\
Eye diameter & -0.0671 & 0.0275 & 0.0929 \\
Post-orbital head length & 0.1730 & 0.1212 & -0.01411 \\
Inter-orbital width & 0.1131 & 0.0311 & -0.0267 \\
Inter-narial width & -0.0175 & 0.0100 & 0.0304 \\
\hline
\end{tabular}

\section{Amblypharyngodon grandisquamis Jordan \& Starks, 1917}

Figure 4

Amblypharyngodon melettinus, Non-Valenciennes, 1844 (from Sri Lanka): Günther 1868: 202; Day 1878: 555; Day 1889: 292; Duncker 1912: 265; Deraniyagala 1952: 45; Senanayake 1980: 167; Pethiyagoda 1991: 25; Pethiyagoda 2006; MOE 2012; De Silva et al. 2015.

Material examined (all from Sri Lanka). SU 22868, 8 paratypes, 56.4-65.4 mm SL, river at Colombo (presumably the Kelani, which is the only river in the vicinity of the city); WHT 30275, 6, 65.0-76.4 mm SL, Bolgoda River basin, Bellanwila-Attidiya; WHT 64, 3, 45.4-47.5 mm SL, Kalu River basin, Ingiriya, Dombagaskanda; WHT 22, 2, 37.2-38.7 mm SL, Kalu River basin, Walandure, Kuruwita; WHT 225, 2, $30.2-$ 34.3 mm SL, Kalu River basin, Ekneligoda, Kuruwita; WHT 30790, 3, 49.3-52.8 mm SL, Kelani River basin, Deraniyagala; WHT 32, 3, 49.6-60.1 mm SL, Attanagalu Oya basin, Weliweriya; WHT 30260, 58.2 mm SL, Nilwala River basin, Godapitiya, Akuressa; WHT 30167, 3, 54.2-74.7 mm SL, Malwathu Oya basin, Anuradhapura; DZ 3193, 7, 57.2-74.0 mm SL, Mahaweli River basin, Polonnaruwa; DZ 3564, 2, 57.2-62.3 mm SL, Mahaweli River basin, Badulu Oya, Kandeketiya; WHT 1694, 3, 
42.7-45.1 mm SL, Mahaweli River basin, Wasgamuwa; WHT 45, 4, 54.6-71.9 mm SL, Mi Oya basin, Puttlam; WHT 1810, 4, 40.8-52.4 mm SL, Kirindi Oya basin, Weerawila; WHT 1851, 41.2 mm SL, Gal Oya basin, Rathugala near Bibile. Cleared and stained: WHT 11075, $64.2 \mathrm{~mm}$ SL, Bolgoda River basin, Bellanwila-Attidiya; WHT 11046, 54.2 mm SL, Mi Oya basin, Puttlam; WHT 11081, 45.1 mm SL, Mi Oya basin, Puttlam; WHT 11052, 45.9 mm SL, Kelani River basin, Deraniyagala; WHT 11070, 40.0 mm SL, Kelani River basin, Deraniyagala. Other material (identified for distribution data, but not measured): WHT 30789, Mahaweli River basin, Wasgamuwa; DZ 3434, Mahaweli River basin, Naula; DZ 1504, Mahaweli River basin, Ulhitiya; WHT 30263, Deduru Oya basin, Wewagama, Kuliyapitiya; WHT 30679, Deduru Oya basin; WHT 2158, Kirindi Oya basin, Tissamaharama; DZ 4423, Kirindi Oya basin, Lunugamwehera; WHT 30723, Heda Oya, Lahugala; WHT 30310, Kala Oya basin, Eluwankulam; WHT 30167, Malwathu Oya basin, Anuradhapura; DZ 4042, Attanagalu Oya basin, Yakkala; DZ 3577, Mi Oya basin, Galgamuwa; DZ 3292, Kalu River basin, Remuna.

Diagnosis. Amblypharyngodon grandisquamis is distinguished from A. melettinus by having a deeper body (26.9-31.2\% SL in $A$. grandisquamis, vs. 22.9-26.3 in A. melettinus); fewer pored lateral-line scales (8-16 (25), 19 (1), vs. 15(1), 17-21 (13) in A. melettinus: Figure 3A); more caudal vertebrae (18-19 (5), vs. 17 (2) in A. melettinus); 2-4 minute foramina (absent in A. melettinus) in addition to a large foramen on the base of the lateral arm of the fifth ceratobranchial; and absence of a minute foramen at the base of the medial arm of the fifth ceratobranchial (present in A. melettinus). It differs from $A$. microlepis by having fewer scales in the lateral series (42-56 vs. 55-65 in $A$. microlepis) and a greater body depth (26.9-31.2\% SL vs. 24.3-26.3 in A. microlepis); from $A$. mola by a lesser dorsal-fin height $(21.1-27.6 \%$ SL vs. 27.8-29.2 in $A$. mola), shorter eye diameter (22.7-30.5\% HL vs. 31.3-36.6 in A. mola), fewer scales in the lateral series (42-56 vs. 69-73 in A. mola: Figure 3B), fewer circumpeduncular scales (20-24 vs. 27-31 in $A$. mola: Figure 3C), and fewer scale rows between the origins of the dorsal and pelvic fins (14-17 vs. 23-25 in $A$. mola: Figure 3D); from $A$. chulabhornae by having more pored lateral-line scales (8-16 (25) or 19 (1) vs. 6-7 in A chulabhornae) and more vertebrae (33-34 (5) vs. 31-32 in $A$. chulabhornae); and from $A$. atkinsonii by having fewer scales in the lateral series (42-56 vs. 55-61 in $A$. atkinsonii), a lesser body depth (26.9-31.2\% SL, vs. 40.5 in A. atkinsonii), and fewer scale rows between the origins of the dorsal and pelvic fins (14-17 vs. 21 in $A$. atkinsonii).

Description. For general appearance, see Figure 4; morphometric data are provided in Table 5. Head and body oblong, slightly compressed. Head wider than body. Body depth greatest at dorsal-fin origin. Snout short, subequal to eye diameter, dorsally rounded, laterally subtriangular. Mouth terminal; symphysial knob present, small, elongated, fitting into shallow groove on inner margin of upper jaw with mouth closed.

Lateral line incomplete, with 8 (1), 9 (2), 10 (4), 11 (4), 12 (6), 13 (5), 15 (1), 16 (2) or 19 (1) pored scales, 42 (1), 44 (1), 45 (4), 46 (3), 47 (4), 48 (4), 49 (2), 50 (1), 51 (1), 52 (2), 53 (2) or 56 (1) scales in lateral series plus 2-4 scales on base of caudal fin. 
A

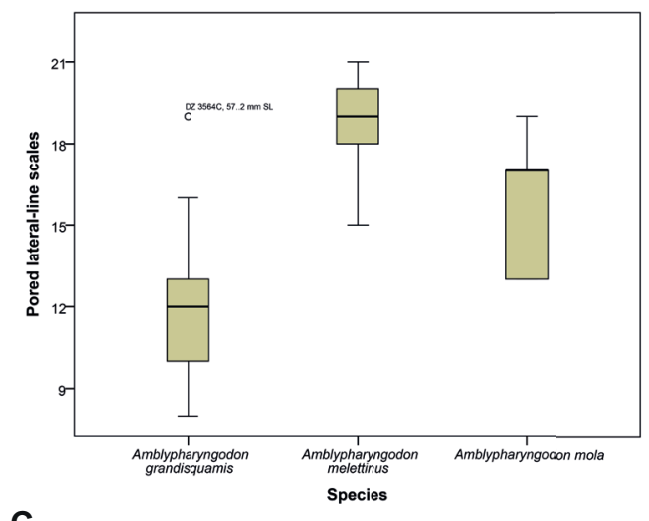

C

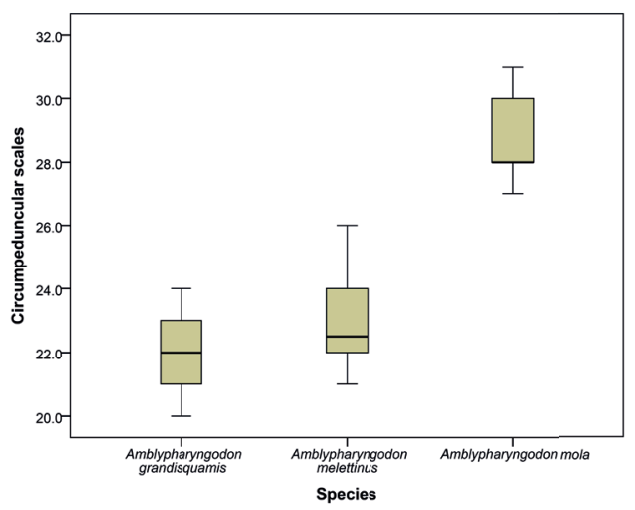

B

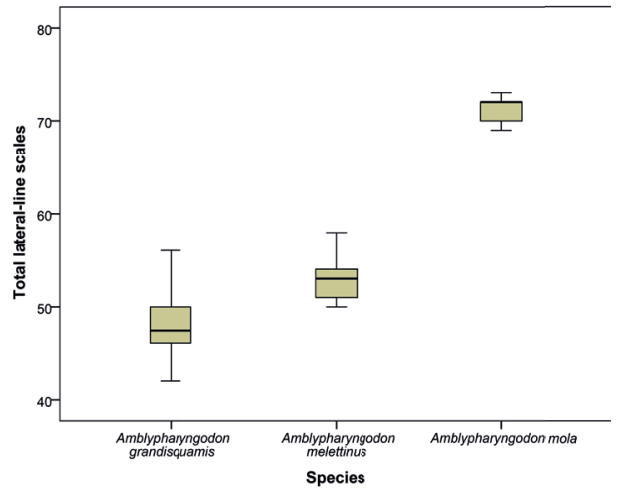

D

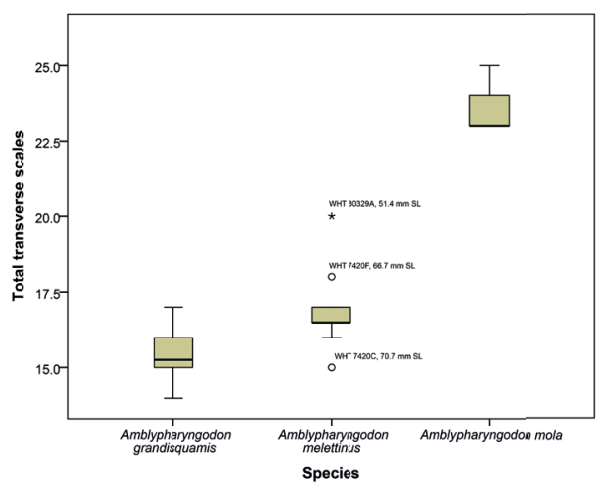

Figure 3. Boxplots representing the distribution of $\mathbf{A}$ pored lateral-line scales $\mathbf{B}$ lateral series scales $\mathbf{C}$ circumpeduncular scales and $\mathbf{D}$ total transverse scales in recent material of $A$. grandisquamis, A. melettinus, and A. mola.

Predorsal scales 27 (2), 28 (3), 29 (2), 30 (2) or 32 (1). Prepelvic scales 25 (1), 26 (1), 27 (1), 28 (1), 29 (1), 30 (2), 31 (1), 33 (1) or 34 (1). Lateral scale rows between origins of dorsal and pelvic fins $1 / 28+1+51 / 2(1), 1 / 28+1+6(1), 1 / 29+1+41 / 2(2), 1 / 29+1+51 / 2$ (8), $1 / 29+1+6$ (1), $1 / 29+1+6^{1 / 2}$ (2), $1 / 210+1+4^{1 / 2}(1), 1 / 210+1+5$ (1), $1 / 210+1+51 / 2$ (4), or $1 / 210+1+61 / 2$ (5). Circumpeduncular scales 20 (2), 21 (7), 22 (10), 23 (5) or 24 (2).

Dorsal fin with two unbranched and seven branched rays, its origin just posterior to vertical through pelvic-fin origin, its distal margin straight. Anal fin with three unbranched and five branched rays, its origin slightly posterior to vertical through origin of dorsal fin, its distal margin slightly concave. Pectoral fin with a single unbranched and 11 (1), 12 (10), 13 (2), or 14 (1) branched rays, its origin anterior to posteriormost point of opercular opening, not reaching pelvic-fin origin when adpressed. Pectoral-fin axillary lobe rudimentary. Pelvic fin with one unbranched and 7 (3) or 8 (13) branched rays, its origin slightly closer to anal-fin origin than to origin of pectoral fin, its tip not reaching anal-fin origin when adpressed. Pelvic 'axillary' scale present. Caudal fin with 9 +8 (14) branched rays, forked, lobes rounded distally, upper and lower lobes subequal. 

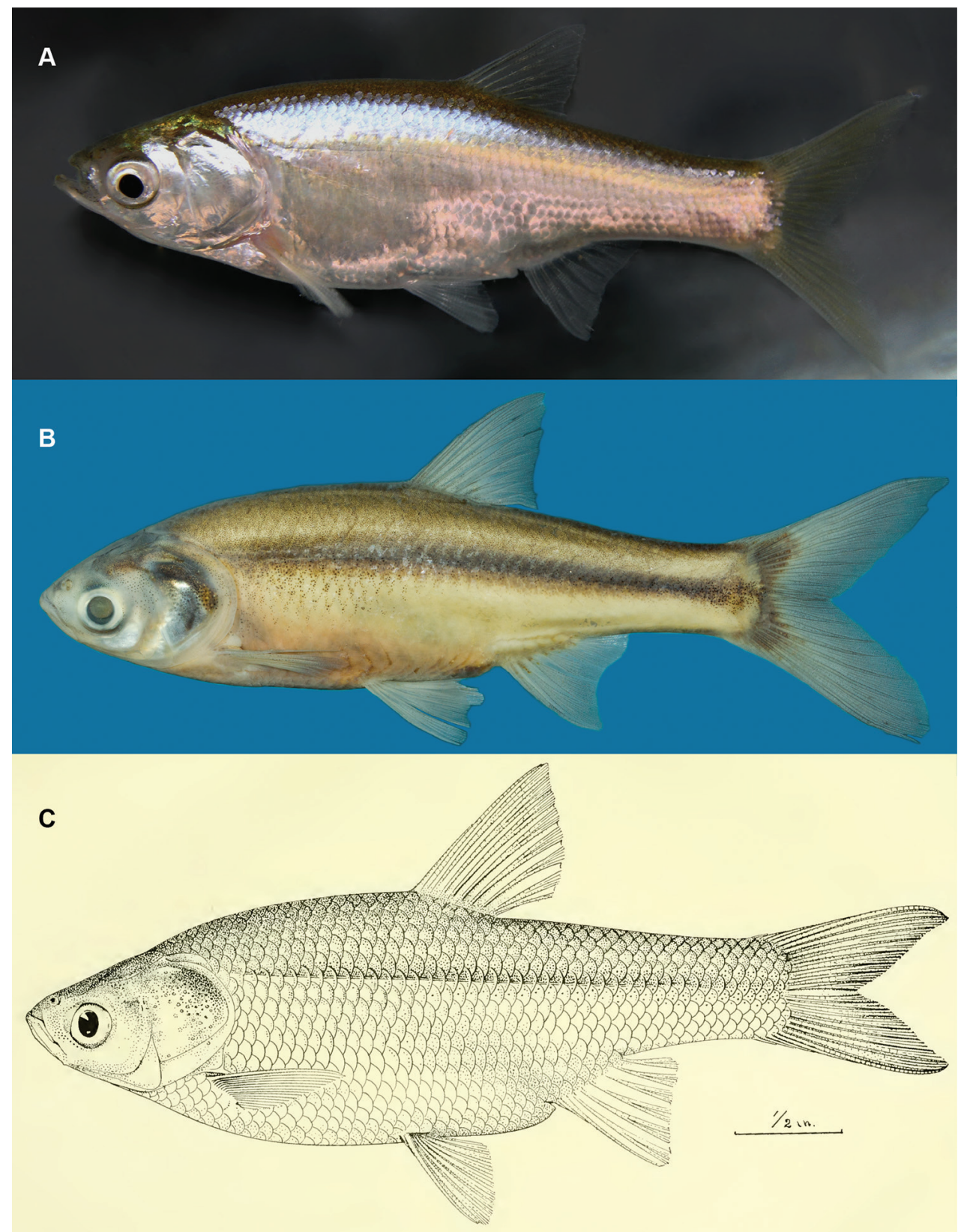

Figure 4. Amblypharyngodon grandisquamis, A in aquarium ( $-70 \mathrm{~mm} \mathrm{SL}$, not collected), Sri Lanka, Ulhitiya, Mahaweli River basin B in preservation (DZ 3193A, 74.0 mm SL), Sri Lanka, Polonnaruwa, Mahaweli River basin C illustration of the holotype of $A$. grandisquamis by Jordan and Starks (1917: pl. XLIV, FMNH 58964). 


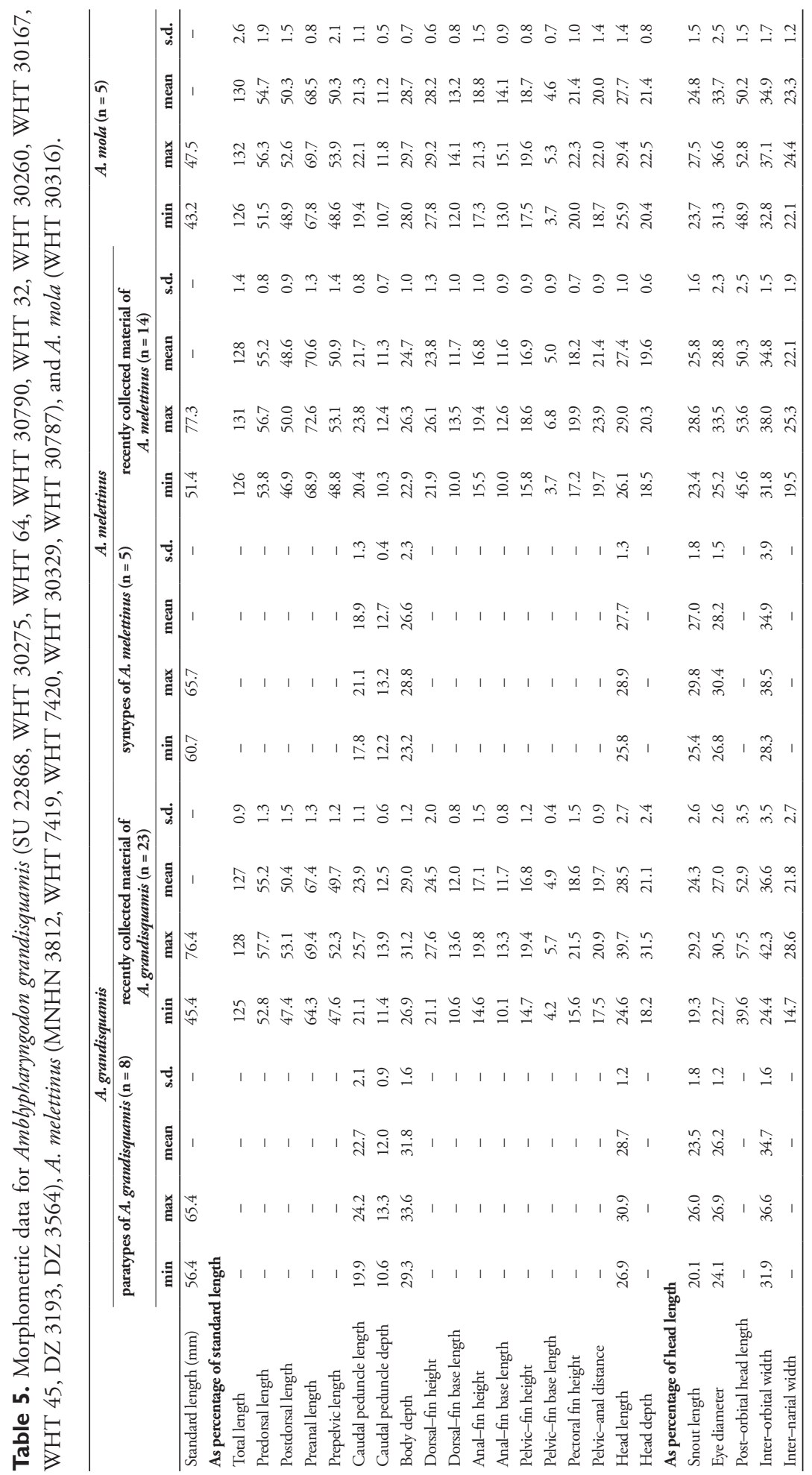


A

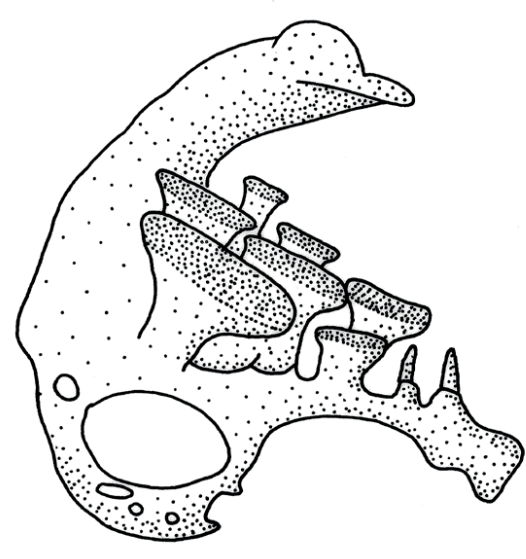

C

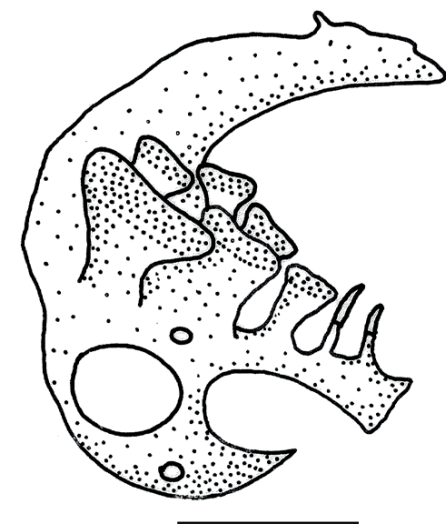

B

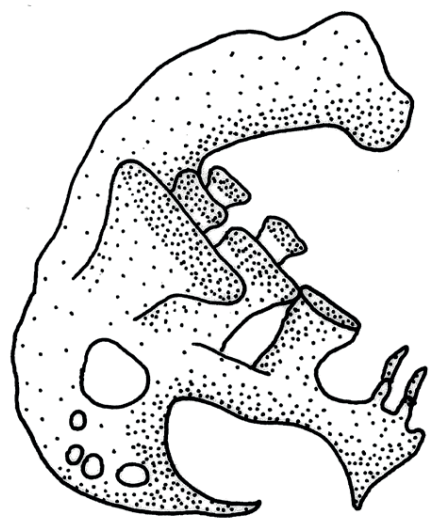

D

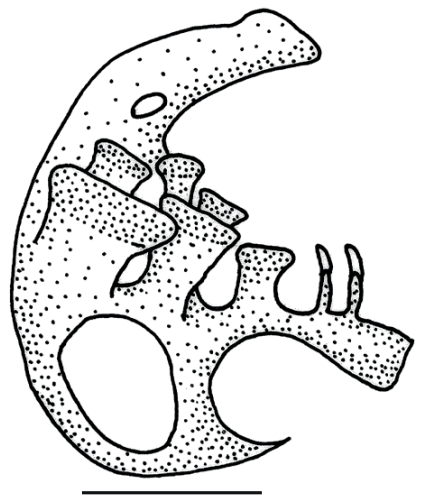

Figure 5. Comparison of the fifth ceratobranchial of A-C Amblypharyngodon grandisquamis and $\mathbf{D} A$. melettinus. A WHT 11075, $64.2 \mathrm{~mm}$ SL B WHT 11046, $54.2 \mathrm{~mm}$ SL C WHT 11070, $40.0 \mathrm{~mm}$ SL D WHT 11072, $57.6 \mathrm{~mm}$ SL. Scale bar: $1 \mathrm{~mm}$.

Vertebrae $15+18=33(1), 15+19=34(4)$. Pharyngeal teeth $5+2+1(4), 5+3$ +1 (1) (Figure 5A-C). Fifth ceratobranchial with 2-4 minute foramina in addition to a large foramen at base of lateral arm; no foramen at base of medial arm (Figure 5A-C).

Coloration. In 70\% alcohol (Figure 4B), head and body silvery brown, darker dorsally, becoming lighter laterally, off-white ventrally. Head darker than body. Duskybrown stripe $1-1 \frac{1}{2}$ scales wide on side of body, from immediately behind operculum, extending to caudal fin base, broader at middle, scales above it with prominent melanophores throughout, scales below it with scattered melanophores on margins, disappearing ventrally. Fins hyaline. Dorsal and caudal fins with scattered melanophores, more prominent on caudal fin.

In life (Figure 4A), head and body silvery grey to iridescent gold, lighter laterally. Scattered melanophores on side of body. A faint yellowish stripe extending from behind operculum to caudal fin base. Caudal fin yellowish, other fins mostly hyaline. 
Habitat, distribution, and natural history. Amblypharyngodon grandisquamis occurs in lotic habitats such as rivers and canals as well as in lentic habitats such as reservoirs and marshes. The species is recorded primarily from the lowland floodplain of Sri Lanka, in both the dry and the wet zones of the island (annual precipitation less than, and greater than, 2,000 $\mathrm{mm}$, respectively), though much more frequently encountered in the dry zone (Figure 6). The highest elevation from which we recorded $A$. grandisquamis was at ca $460 \mathrm{~m}$ a.s.l., in the Samanala reservoir on the Walawe River basin. It is a slow-swimming fish, usually encountered in large groups close to the surface. With the onset of the rains, adults are observed in rice paddies, probably migrating there to spawn. The relative abundance of $A$. grandisquamis, at least in the wet zone, appears to be seasonal, with more adults usually observed during the rainy season.

\section{Discussion}

While Menon (1999) did not consider $A$. mola to occur in the peninsula of India, most other recent authors (e.g., Talwar and Jhingran 1991, Jayaram 2010), following Day (1878), recognise three species of Amblypharyngodon from the peninsula: A. melettinus, A. microlepis and $A$. mola. We therefore discuss the identity of each of these in the context of $A$. grandisquamis.

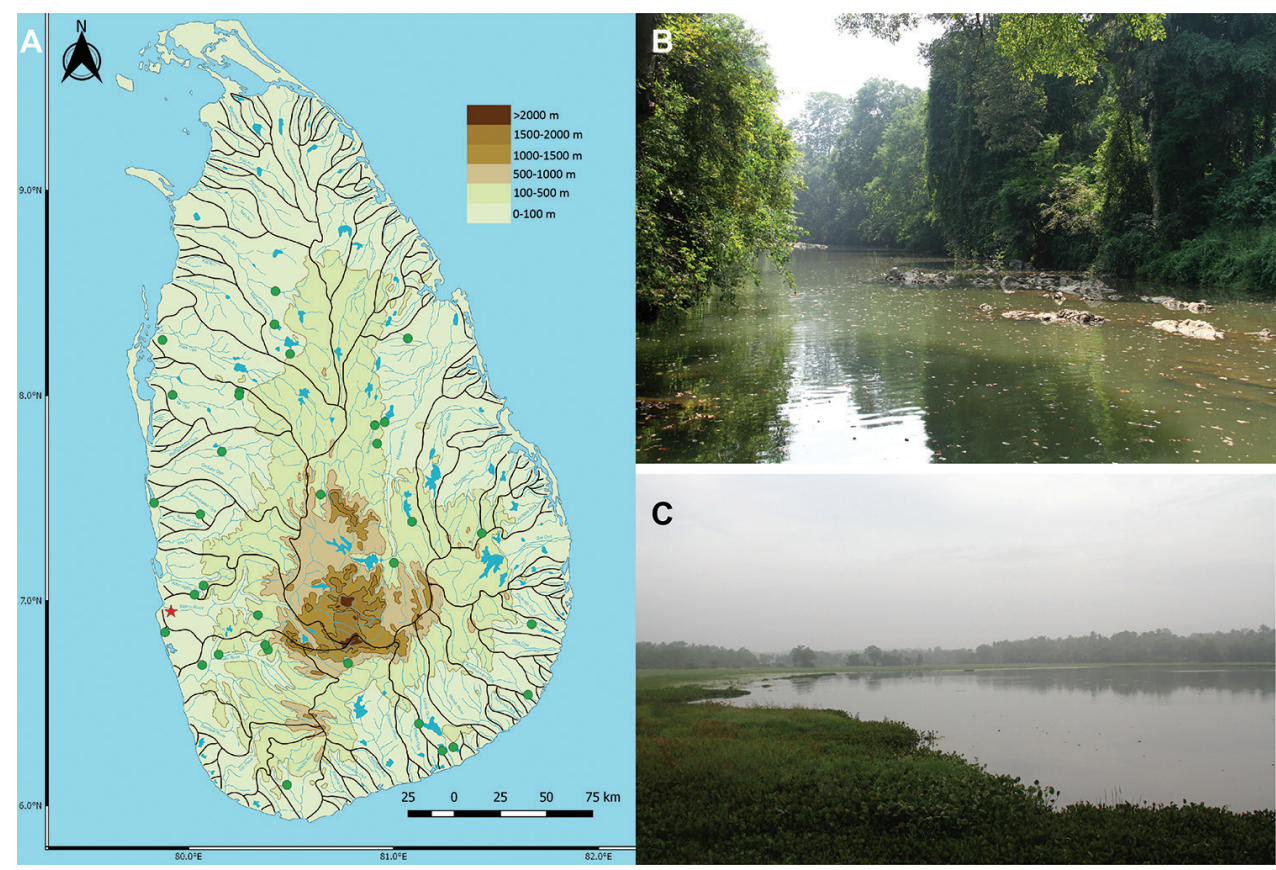

Figure 6. A Distribution of Amblypharyngodon grandisquamis in Sri Lanka. Present records (green) and the type locality (red); habitat of $A$. grandisquamis in B Badulu Oya, Kandeketiya and $\mathbf{C}$ a reservoir at Galgamuwa. 


\section{Amblypharyngodon melettinus}

The species we here refer to Amblypharyngodon grandisquamis was first reported from Sri Lanka by Günther (1868: 202) and Day (1878: 555), as Amblypharyngodon melettinus (Valenciennes 1844). Although Günther (1868) gave the distribution of $A$. melettinus as "Bombay; Coast of Malabar; Ceylon [= Sri Lanka]", it is clear from the listing of material at the end of his description that he had not seen specimens from Bombay. For his part, Day (1878) had the distribution of this species as "(Bombay, according to Cuv. and Val.) Malabar coast, and southern India, from the Neilgherries to Madras", making it clear that he too, had not seen specimens from Bombay. As such, the conception of $A$. melettinus by these authors was based essentially on the original description of Valenciennes (1844) and specimens from southern peninsular India and Sri Lanka: neither Günther (1868) nor Day (1878) had opportunity to examine the type specimens in Paris.

The syntypes of $A$. melettinus are in quite poor condition. Jean-Jacques Dussumier probably collected these on his visit to Bombay 1827-30 (see Bauchot et al. 1990: 46). We have been unable to determine whether, when Valenciennes (1844) gave the type locality as Bombay, he meant the city of Bombay (now Mumbai) or the erstwhile Bombay Presidency. The latter, in the mid- $19^{\text {th }}$ century, encompassed a vast territory inland of British India’s Arabian-sea coastline, extending from southern Karnataka across the Sindh Province of present-day Pakistan and on to Yemen (Collen 1909). The result of this uncertainty has been that subsequent authors (e.g., Talwar and Jhingran 1991, Menon 1999, Jayaram 2010) appear to have followed Day's (1878) conception of $A$. melettinus as the species of Amblypharyngodon inhabiting the south-western region of the Indian peninsula, characterised by the lateral line being incomplete, with 15-20 pored scales, and with 50-57 scales in the lateral series and 4 scale-rows between the lateral-line row and the pelvic-fin origin. These counts are broadly consistent with the original description of $A$. melettinus, "more than fifty rows of scales along the flanks..." (Valenciennes 1844: 305) and those syntypes in which scales can reliably be counted. The latter possess 16-21 pored lateral-line scales and 48-55 scales in the lateral series, plus a further 2-3 on the caudal-fin base. While these counts overlap partly with those of $A$. grandisquamis (8-16, rarely up to 19 pored lateral-line scales, $42-56$ scales in lateral series on body), the eight paratypes of $A$. grandisquamis (SU 22868) are distinguished from the five syntypes of $A$. melettinus (MNHN 3812) by their greater body depth (29.3-33.6\% SL, vs. 23.2-28.8\% SL), bearing in mind that evisceration and age have resulted in the latter specimens becoming somewhat compressed and hence appearing deeper-bodied (see Figure 7A). Nevertheless, the body depth in recently collected $A$. grandisquamis $(\mathrm{N}=23)$ is $26.9-31.2 \% \mathrm{SL}$, while that in recently collected $A$. melettinus $(\mathrm{N}=14)$ is $22.9-26.3$, and the two species are easily distinguished by the deeper body of the former.

Our search for recent specimens of $A$. melettinus from the vicinity of Mumbai led to the examination of two specimens of Amblypharyngodon, BNHS 560-61, 44.5 and $56.8 \mathrm{~mm}$ SL, from Tilase on the Vaitarna River, Maharashtra, ca. 50 km from Mum- 
bai. These have 66 and 67 scales in the lateral series, 25 and 27 scale rows between the dorsal- and pelvic-fin origins, and 31 and 35 circumpeduncular scales. Although these meristics are suggestive of $A$. mola, these specimens group with $A$. melettinus in morphological space (Figure $2 \mathrm{~B}$ ). We provisionally assign them to $A$. mola noting that Wahab et al. (2003) observed that $A$. mola is popularly used in aquaculture in India along with other species of fish and prawns, which may explain its presence in the Vaitarna. Wagh and Ghate (2002) too, recorded A. mola from Mula and Mutha rivers of Maharashtra.

\section{Amblypharyngodon microlepis}

In differentiating $A$. microlepis from $A$. melettinus, Bleeker (1853: 141) relied primarily on the erroneous assumption that the lateral line was complete in the latter: "It has such a great resemblance to Leuciscus melettina...", observed Bleeker (1853), "that it might be kept to the same [species]. In Leuciscus melettina, however, the lateral line goes up to the caudal fin, the scales are somewhat fewer and, at least according to the picture, the pectoral fins appear a little longer than the head."

Bleeker was evidently misled by the illustration of $A$. melettinus that accompanied the original description (Valenciennes 1844: pl. 501, reproduced here as Figure 7C), which seems to show a complete lateral line. In the syntypes of $A$. melettinus, as noted also above, the lateral line extends only to the first 16-21 scales (Valenciennes did not provide a scale count in the original description); see also Figure 7A, which shows a $65.7 \mathrm{~mm}$ syntype (MNHN 3812), in which the lateral line consists of approximately 20 pored scales, terminating just posterior to the pelvic-fin origin.

Bleeker's (1853) original description of A. microlepis contains some information of diagnostic value, including that the lateral line terminates just anterior to the tip of the pectoral fin, the lateral-line series consisting of 60 scales; that there were 20 scale-rows in transverse line on the body; and that the dorsal-fin origin lay between the pelvic-fin origin and anal-fin origin.

Vidthayanon and Kottelat (1990), however, examined four specimens from Bengal (RMNH 7043) identified as A. microlepis by Bleeker, reporting that these contained 58-65 scales in the lateral-line series, the first 8-12 of which were perforated; and had a body depth of 24.3-26.3\% SL. The specimen AMS B7593, from Orissa, India, identified as $A$. microlepis by Day, has 55 scales in the lateral-line series. These data enable $A$. microlepis to be unambiguously distinguished from $A$. grandisquamis, which has 42-56 scales in lateral series and a body depth of $26.9-31.2 \%$ SL.

\section{Amblypharyngodon mola etc.}

Amblypharyngodon grandisquamis is easily distinguished from $A$. mola by possessing fewer scales in the lateral series: $42-56$, vs. $69-73$ in $A$. mola from the putatively topotypical West Bengal specimens examined by us, 65-79 in the Orissa specimens 

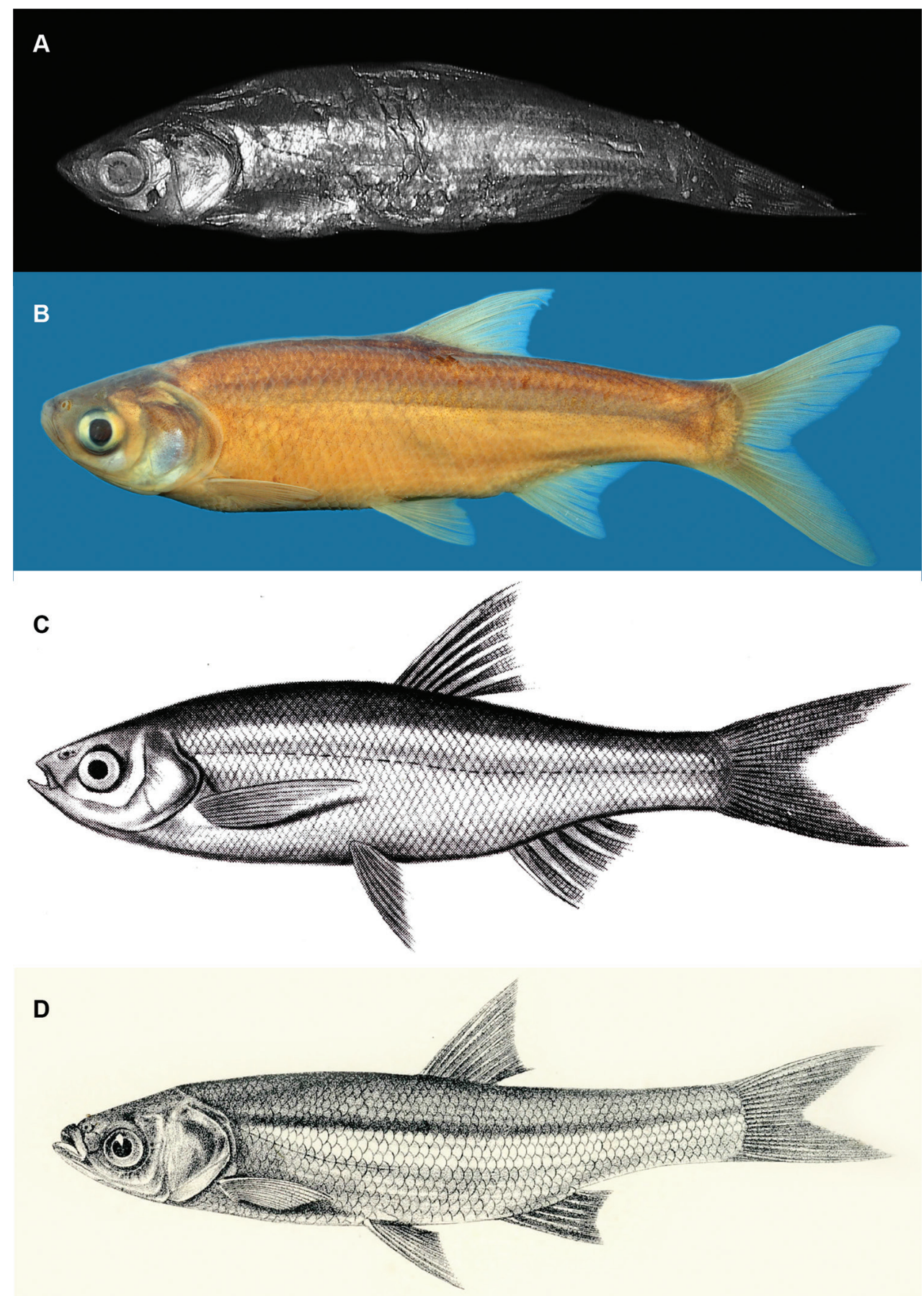

Figure 7. A syntype of Amblypharyngodon melettinus, MNHN 3812, $65.7 \mathrm{~mm} \mathrm{SL}$, India, Bombay B specimen of $A$. melettinus, WHT 7419A, $72.2 \mathrm{~mm} \mathrm{SL}$, India, Kerala, Kumarakom, Kottayam C illustration of $A$. melettinus by Valenciennes (1844: pl. 501) D illustration of $A$. melettinus by Day (1878: pl. CXXXIV, fig. 3), laterally inverted. 
examined by Vidthayanon and Kottelat (1990), and 65-75 reported by Day (1878: 555) from across the species' range in India. Additionally, A. grandisquamis differs from A. mola by having a shorter dorsal fin, smaller eye, fewer circumpeduncular scales and fewer lateral scale rows (see Diagnosis).

There remain five additional nominal species of Amblypharyngodon reported from the Indian peninsula: A. chakaiensis Babu Rao and Nair (type locality the Chakai backwater near Trivandrum [Thiruvananthapuram], Kerala); Leuciscus chitul Sykes ('Inderance River near Chakun, Deccan'); Rhodeus indicus Jerdon (Palghat [Palakkad] River, Kerala); Brachygramma jerdonii Day (Cochin [Kochi], Kerala); and Rhodeus macrocephalus Jerdon (Cavery [Kaveri] River and Carnatic [Karnataka], southern India). Except for $A$. jerdoni, which Day (1878: 555) himself relegated to the synonymy of $A$. melettinus, none of these is represented by type material or accompanied by a description enabling differential diagnosis with congeners. Elucidation of their identity must necessarily await a revision based on fresh collections in India. We note, however, that Day (1878), who was last to review the Indian species of Amblypharyngodon, considered $A$. indicus and $A$. jerdoni to be synonyms of $A$. melettinus; and $A$. chitul and $A$. macrocephalus synonyms of $A$. mola. Amblypharyngodon chakaiensis, distinguished from A. melettinus by Babu and Nair (1978) in having 16 pectoral-fin rays and six scale-rows between the lateral line and pelvic fin base, has been treated as valid by some subsequent authors (e.g., Talwar and Jhingran 1991, Jayaram 2010) and as a synonym of $A$. melettinus by others (e.g., Menon 1999). No type material of $A$. chakaiensis is known, and an attempt in 1996 by one of us (RP) to recollect topotypes from the Aakulam 'lake' at Chacka, a suburb of Thiruvananthapuram, was abandoned owing to the high degree of aquatic pollution. In any event, $A$. grandisquamis can be unambiguously diagnosed from $A$. chakaiensis by having only 11-14 (14) branched pectoral-fin rays (vs. 16 in A. chakaiensis), although this by itself is hardly a character by which cyprinid species can be validated.

\section{Genetic analysis}

While our genetic analysis clearly separates $A$. grandisquamis from its peninsular-Indian congeners $A$. melettinus and $A$. mola, it does not fully resolve the sister-group relationships of $A$. grandisquamis. Our COI and the COI+16s combined analyses recover $A$. melettinus as the sister group of [A. grandisquamis $+A$. mola], whereas our $16 \mathrm{~s}$ phylogram recovers $A$. mola as the sister group of [A. grandisquamis $+A$. melettinus].

The uncorrected pairwise genetic distances for COI between $A$. grandisquamis and A. melettinus, A. mola and A. chulabhornae, of $9 \%, 6 \%$ and $10 \%$, respectively, are consistent with the distances observed between independently validated species (Ward 2009), lending confidence to our consideration of $A$. grandisquamis as a valid species.

The non-significant results of the neutrality tests suggest that there has been no recent range expansion or population bottleneck in A. grandisquamis in Sri Lanka. 


\section{Conservation}

Jordan and Starks (1917) described the type locality of $A$. grandisquamis as "river at Colombo". The only river that drains Colombo is the Kelani, which then should fix the type locality (Pethiyagoda 1991: 25). Though still recorded in some marshes and reservoirs in the suburbs of Colombo, $A$. grandisquamis is met with less frequently in the 'wet zone' (precipitation more than 2,000 mm/y) of the island's southwestern quarter, within which Colombo lies, than in the 'dry zone' (precipitation less than $2,000 \mathrm{~mm} / \mathrm{y}$ ). There is no basis to the claim made by De Silva et al. (2015) that $A$. grandisquamis is restricted to the wet zone while $A$. melettinus is widely distributed in the dry zone.

The National Red List of Sri Lanka (MOE 2012) assesses A. grandisquamis as Endangered (presumably because it is endemic) and $A$. melettinus as Least Concern. There is, however, only a single species of Amblypharyngodon inhabiting in Sri Lanka, adding weight to the recommendation by Sudasinghe et al. (2018b) that conservation plans be predicated on sound taxonomy. Amblypharyngodon grandisquamis is exploited in the fishery and accounts for the highest biomass production among minor indigenous cyprinids in Sri Lanka (Pet et al. 1996). Nevertheless, given its wide distribution across the island's lowlands, and its abundance in the dry zone, where inland fisheries are most intensive, $A$. grandisquamis is not a species of immediate conservation concern.

Bossuyt et al. (2004) showed that despite Sri Lanka having been terrestrially connected to southern peninsular India during glacial sea-level low-stands until the Holocene, endemism within several faunal groups, including freshwater fishes, is much higher on the island than had previously been suspected. This inspired authors to subject Sri Lankan fishes until then ascribed to 'Indian' species to review the identities of the island's freshwater fishes through morphological and molecular comparisons with their Indian congeners, showing them in many cases to be insular endemics: e.g., Mystus zeylanicus Ng and Pethiyagoda (2013); Pethia melanomaculata (Deraniyagala), Batuwita et al. (2015); M. nanus Sudasinghe et al. (2016); Ompok ceylonensis (Günther) and $O$. argestes Sudasinghe and Meegaskumbura (2016); Labeo lankae Deraniyagala and L. heladiva Sudasinghe et al. (2018a). Amblypharyngodon grandisquamis becomes the latest such species, and is unusual among Sri Lanka's endemic freshwater fishes in that its range spans both principal climatic zones, a distribution otherwise observed in only three of the approximately 50 endemics now recognised in the island.

\section{Conclusions}

Since the description of $A$. grandisquamis by Jordan and Starks (1917) from Sri Lanka, the identity of the species of Amblypharyngodon inhabiting the freshwaters of the island has been confused for most of the past century. Two species, $A$. grandisquamis and $A$. 
melettinus, had been frequently recognised in the Sri Lankan literature without, however, a specimen-based study. Here, by incorporating both morphological and molecular data, we conclude that only a single species of Amblypharyngodon (A. grandisquamis) occurs in the island, which is, morphologically as well as genetically distinct from the species of Amblypharyngodon in the Indian peninsula.

\section{Acknowledgments}

HS and MM are grateful to the Director General of Wildlife Conservation and the Conservator General of Forests, Sri Lanka, for permits to carry out fieldwork. HS thanks Rahul Kumar, Rajeev Raghavan, and Unmesh Katwate for useful discussions, providing generous hospitality during a visit to India and allowing access to Indian material in their collections; Sanuja Kasthuriarachchi, Director of National Museums, and Lankani Somarathna and her staff, for access to specimens; the Wildlife Heritage Trust of Sri Lanka for providing financial support for this research; and finally Charana Widuranga, Dhanushka Lakshan, Kumudu Wijesooriya, and R.H. Tharindu Ranasinghe for their assistance in the field. RP thanks Patrice Pruvost and Zara Gabsi (MNHN), Mark McGrouther and Amanda Hay (AMS), and David Catania (CAS) for kind hospitality and access to specimens in their care. Finally, we thank Rupert Collins, Seigo Kawase, Sven Kullander, and two anonymous reviewers for constructive comments on the original draft of this manuscript.

\section{References}

Batuwita S, Maduwage K, Sudasinghe H (2015) Redescription of Pethia melanomaculata (Teleostei: Cyprinidae) from Sri Lanka. Zootaxa 3936: 575-583. https://doi.org/10.11646/ zootaxa.3936.4.7

Babu RM, Nair NB (1978) On a new species of Amblypharyngodon (Cyprininae - Cyprinidae) from Trivandrum (Kerala, India). Aquatic Biology 3: 121-125.

Bauchot ML, Daget J, Bauchot R (1990) L'ichtyologie en France au début du XIXè siècle: L'histoire naturelle des poissons de Cuvier \& Valenciennes. Bulletin du Muséum National d'Histoire Naturelle, Paris, Sect. A, Sér. 4, 12(1, Suppl.): 1-142.

Bleeker P (1853) Nalezingen op de ichthyologische fauna van Bengalen en Hindostan. Verhandelingen van het Bataviaasch Genootschap van Kunsten en Wetenschappen 25: 1-164. https://doi.org/10.5962/bhl.title.60451

Bossuyt F, Meegaskumbura M, Beenaerts N, Gower DJ, Pethiyagoda R, Roelants K, Mannaert A, Wilkinson M, Bahir MM, Manamendra-Arachchi K, Schneider CJ, Oommen OV, Milinkovitch MC (2004) Local endemism within the western Ghats-Sri Lanka biodiversity hotspot. Science 306: 479-481. https://doi.org/10.1126/science.1100167

Clement M, Snell Q, Walke P, Posada D, Crandall K (2002) TCS: estimating gene genealogies. Proceedings of the $16^{\text {th }}$ International Parallel and Distributed Processing Symposium (USA), April 2002. 2: 184. https://doi.org/10.1109/IPDPS.2002.1016585 
Collen E (1909) Imperial gazetteer of India: The Indian Empire; Vol. 4: Administrative. Clarendon Press, Oxford, 552 pp.

Conway KW (2011) Osteology of the South Asian genus Psilorhynchus McClelland, 1839 (Teleostei: Ostariophysi: Psilorhynchidae), with investigation of its phylogenetic relationships within the order Cypriniformes. Zoological Journal of the Linnean Society 163: 150-154. https://doi.org/10.1111/j.1096-3642.2011.00698.x

Cuvier G, Valenciennes A (1844) Histoire naturelle des poissons. Tome seizième. Livre dixhuitième. Les Cyprinoïdes 17: 1-497. [pls 487-519]

Darriba D, Taboada GL, Doallo R, Posada D (2012) jModelTest 2: more models, new heuristics and parallel computing. Nature methods 9: 772. https://doi.org/10.1038/nmeth.2109

Day F (1878) Fishes of India, Part 4. Quaritch, London, 553-778. [pls 134-195]

Day F (1889) The Fauna of British India, including Ceylon and Burma. Fishes Vol. 1. Taylor \& Francis, London, 548 pp.

Dayrat B (2005) Towards integrative taxonomy. Biological Journal of the Linnean Society 85: 407-415. https://doi.org/10.1111/j.1095-8312.2005.00503.x

De Silva MA, Hapuarachchi N, Jayaratne T (2015) Sri Lankan Freshwater Fishes. Wildlife Conservation Society, Galle, 391 pp.

Deraniyagala PEP (1952) A coloured atlas of some vertebrates from Ceylon, Vol. 1. Fishes. National Museums of Ceylon, Colombo, 149 pp. [34 pls]

Duncker G (1912) Die Süßwasserfische Ceylons. Mitteilungen aus dem Naturhistorischen (Zoologischen) Museum in Hamburg 29: 241-272. [1 pl.]

Elliott NG, Haskard K, Koslow JA (1995) Morphometric analysis of orange roughy (Hoplostethus atlanticus) off the continental slope of southern Australia. Journal of Fish Biology 46: 202-220. https://doi.org/10.1111/j.1095-8649.1995.tb05962.x

Fu YX, WH Li (1993) Statistical tests of neutrality of mutations. Genetics 133: 693-709.

Guindon S, Gascuel O (2003) A simple, fast and accurate method to estimate large phylogenies by maximum-likelihood. Systematic Biology 52: 696-704. https://doi. org/10.1080/10635150390235520

Günther A (1868) Catalogue of the fishes in the British Museum. Vol. 7. Catalogue of the Physostomi containing the families Heteropygii, Cyprinidae, Gonorhynchidae, Hyodontidae, Osteoglossidae, Clupeidae, Chirocentridae, Alepocephalidae, Notopteridae, Halosauridae, in the collection of the British Museum. British Museum, London, 512 pp.

Hammer $\varnothing$, Harper DAT, Ryan PD (2001) PAST: Paleontological Statistics Software Package for Education and Data Analysis. Palaeontologia Electronica 4: 1-9.

Huelsenbeck JP, Ronquist F, Nielsen R, Bollback JP (2001) Bayesian inference of phylogeny and its impact on evolutionary biology. Science 294: 2310-2314. https://doi.org/10.1126/ science. 1065889

Jayaram KC (2010) The Freshwater Fishes of the Indian region ( $2^{\text {nd }}$ edn). Narendra Publishing House, Delhi, 616 pp.

Jordan DS, Starks EC (1917) Notes on a collection of fishes from Ceylon with descriptions of new species. Annals of the Carnegie Museum 11: 430-460. [pls 43-47]

Kumar S, Stecher G, Tamura K (2016) MEGA7: Molecular Evolutionary Genetics Analysis version 7.0 for bigger datasets. Molecular Biology and Evolution 33: 1870-1874. https:// doi.org/10.1093/molbev/msw054 
Leigh JW, Bryant D (2015) PopART: Full-feature software for haplotype network construction. Methods in Ecology and Evolution 6: 1110-1116. https://doi.org/10.1111/2041210X.12410

Menon AGK (1999) Check list - Fresh water fishes of India. Records of the Zoological Survey of India, Occasional Papers 175: 1-366.

MOE (2012) The National Red List 2012 of Sri Lanka; conservation status of the fauna and flora. Ministry of Environment, Colombo, 476 pp.

$\mathrm{Ng} \mathrm{HH}$, Pethiyagoda R (2013) Mystus zeylanicus, a new species of bagrid catfish from Sri Lanka (Teleostei: Bagridae). Ichthyological Exploration of Freshwaters 24: 161-170.

Pet JS, Gevers, GJM, Van Densen WLT, Vijverberg J (1996) Management options for a more complete utilization of the biological fish production in Sri Lankan reservoirs. Ecology of Freshwater Fish 5: 1-14. https://doi.org/10.1111/j.1600-0633.1996.tb00032.x

Pethiyagoda R (1991) Freshwater fishes of Sri Lanka. Wildlife Heritage Trust, Colombo, Sri Lanka, 362 pp.

Pethiyagoda R (2006) Conservation of Sri Lankan freshwater fishes. In: Bambaradeniya CNB (Ed.) Fauna of Sri Lanka: status of taxonomy, research and conservation. The World Conservation Union, Colombo, 103-112.

Rambaut A, Suchard MA, Xie D, Drummond AJ (2014) Tracer v1.6, https://tree.bio.ed.ac.uk/ software/tracer

Ronquist F, Teslenko M, van der Mark P, Ayres DL, Darling A, Höhna S, Larget B, Liu L, Suchard MA, Huelsenbeck JP (2012) MrBayes 3.2: efficient Bayesian phylogenetic inference and model choice across a large model space. Systematic Biology 61: 539-542. https://dx.doi.org/10.1093/sysbio/sys029

Rozas J, Ferrer-Mata A, Sánchez-Del Barrio JC, Guirao-Rico S, Librado P, Ramos-Onsins SE, Sánchez-Gracia A (2017) DnaSP 6: DNA sequence polymorphism analysis of large data sets. Molecular Biology and Evolution 34: 3299-3302. https://doi.org/10.1093/molbev/msx248

Senanayake FR (1980) The Biogeography and ecology of the inland fishes of Sri Lanka. PhD Thesis, Department of Wildlife and Fisheries Biology, University of California, Davis.

Sudasinghe H, Meegaskumbura M (2016) Ompok argestes, a new species of silurid catfish endemic to Sri Lanka (Teleostei: Siluridae). Zootaxa 4158: 261-271. https://doi. org/10.11646/zootaxa.4158.2.7

Sudasinghe H, Pethiyagoda R, Maduwage K, Meegaskumbura M (2016) Mystus nanus, a new striped catfish from Sri Lanka (Teleostei: Bagridae). Ichthyological Exploration of Freshwaters 27: 163-172.

Sudasinghe H, Ranasinghe RHT, Goonatilake SDA, Meegaskumbura M (2018a) A review of the genus Labeo (Teleostei: Cyprinidae) in Sri Lanka. Zootaxa 4486: 201-235. https://doi. org/10.11646/zootaxa.4486.3.1

Sudasinghe H, Herath J, Pethiyagoda R, Meegaskumbura M (2018b). Undocumented translocations spawn taxonomic inflation in Sri Lankan fire rasboras (Actinopterygii, Cyprinidae). PeerJ 6: e6084. https://doi.org/10.7717/peerj.6084

Tajima F (1989) Statistical method for testing the neutral mutation hypothesis by DNA polymorphism. Genetics 123: 585-595. 
Talwar PK, Jhingran AG (1991) Inland fishes of India and adjacent countries. Oxford \& IBH Publishing Company, New Delhi, 2 vols, 1158 pp. [3 pls]

Taylor WR, Van Dyke GC (1985) Revised procedures for staining and clearing small fishes and other vertebrates for bone and cartilage study. Cybium 9: 107-119.

Vidthayanon C, Kottelat M (1990) Amblypharyngodon chulabhornae sp. nov., a new cyprinid fish from Thailand and Kampuchea. Natural History Bulletin of the Siam Society 38: 45-57.

Wagh GK, Ghate HV (2002) Freshwater fish fauna of the rivers Mula and Mutha, Pune, Maharashtra. Zoos' Print Journal 18: 977-981. https://doi.org/10.11609/JoTT.ZPJ.18.1.977-89

Wahab MA, Alim MA, Milstein A (2003) Effects of adding the small fish punti (Puntius sophore Hamilton) and/or mola (Amblypharyngodon mola Hamilton) to a polyculture of large carp. Aquaculture Research 34: 149-163. https://doi.org/10.1046/j.1365-2109.2003.00784.x

Ward RD (2009) DNA barcode divergence among species and genera of birds and fishes. Molecular Ecology Resources 9: 1077-1085. https://doi.org/10.1111/j.1755-0998.2009.02541.x 